Sains Malaysiana 47(7)(2018): 1501-1510

http://dx.doi.org/10.17576/jsm-2018-4707-18

\title{
Penyahbauan Fukoidan dan Kesannya terhadap Ciri Fizikokimia dan Aktiviti Antipengoksidaan
}

(Deodorisation of Fucoidan and Its Effect towards Physicochemical Characteristics and Antioxidation Activities)

\author{
TAN Chia Sin, Sharifah Habibah Syed Khalafu, Wan Aida Wan Mustapha, \\ MOHAMAD YUSOF MASKAT \& SENG JOE LIM*
}

\begin{abstract}
Fukoidan adalah sejenis polisakarida bioaktif yang terdiri daripada fukosa, sulfat dan asid uronik. Fukoidan mempunyai bau hanyir menyebabkan aplikasi dalam produk makanan menjadi sukar. Oleh itu, objektif kajian ini adalah untuk menyahbau hanyir fukoidan yang diekstrak daripada Sargassum sp. $\left(F_{\text {sar }}\right)$ dan mengkaji kesan penyahbauan terhadap ciri-ciri fizikokimia dan aktiviti antipengoksidannya. $F_{\text {sar }}$ dinyahbau dengan menggunakan butiran karbon teraktif $\left(F_{\text {kar }}\right)$, kaedah pengewapan haba $\left(F_{\text {wap }}\right)$ dan gabungan kedua-dua kaedah tersebut $\left(F_{k w}\right)$. Keberkesanan penyahbauan dikenal pasti melalui penilaian sensori (ujian deskriptif kuantitatif) bagi menilai persepsi bau fukoidan yang telah dinyahbau. Ciri fizikokimia iaitu ketulenan, warna dan nilai $\mathrm{pH}$, manakala aktiviti antipengoksidaan ditentukan melalui ujian pemerangkapan radikal bebas (DPPH), aktiviti pemerangkapan superoksida anion (SOA) dan pemerangkapan radikal hidroksil $(\bullet \mathrm{OH})$. Kaedah penyahbauan $F_{k a r}$ menunjukkan nilai keamatan bau hanyir yang paling rendah dan tahap penerimaan keseluruhan yang paling tinggi. Ketulenan $F_{\text {kar }}$ tidak berbeza secara bererti ( $\left.\mathrm{p}>0.05\right)$ berbanding $F_{\text {sar }}$, manakala ketulenan $F_{\text {wap }}$ dan $F_{k w}$ menurun secara signifikan berbanding $F_{\text {sar. }}$ Keempat-empat sampel fukoidan $\left(F_{\text {sar }}, F_{\text {kar }}\right.$, $\left.F_{\text {wap }}, F_{k w}\right)$ menunjukkan warna dan nilai $p H$ berbeza secara signifikan $(\mathrm{p}<0.05)$. Sebaliknya, tiada kesan yang signifikan ( $\mathrm{p}>0.05)$ terhadap kesan antipengoksidaan oleh kempat-empat sampel fukoidan selepas penyahbauan $\left(F_{\text {sar }}, F_{k a r}, F_{w a p}, F_{k w}\right)$. Pada keseluruhannya, kaedah penyahbauan menggunakan karbon teraktif $\left(F_{k a r}\right)$ didapati berpotensi kerana keberkesanan dan tidak menyebabkan perubahan signifikan pada ketulenan dan aktiviti antipengoksidaan fukoidan.
\end{abstract}

ABSTRAK

Kata kunci: Antipengoksidaan; fizikokimia; fukoidan; penyahbauan

\section{ABSTRACT}

Fucoidan is a bioactive polysaccharide made up mainly of fucose, sulphate and uronic acid. However, fucoidan possess a strong fishy odour, which hinders its application in food products. Therefore, the objective of this study was to deodorise fucoidan extracted from Sargassum sp. $\left(F_{\text {sar }}\right)$ and to determine the effect of deodorisation on its physicochemical characteristics and antioxidative activities. $F_{\text {sar }}$ was deodorised using activated carbon granules $\left(F_{k a r}\right)$, heat vaporisation $\left(F_{\text {wap }}\right)$ and the combination of both methods $\left(F_{k w}\right)$. The effectiveness of deodorisation was determined through sensory evaluation (quantitative descriptive analysis) to evaluate the odour perception of the deodorised fucoidan. The physicochemical characteristics of fucoidan that were determined were purity, colour and $\mathrm{pH}$ value, while the antioxidative activities were determined using free radical scavenging assay (DPPH), superoxide anion (SOA) and hydroxyl radical $(\bullet \mathrm{OH})$ scavenging activities. Through deodorisation of fucoidan, $F_{k a r}$ showed the lowest fishy odour intensity and the highest overall acceptability. Besides that, it was found that $F_{\text {kar }}$ 's purity was not significantly different $(\mathrm{p}>0.05)$ compared to that of $F_{\text {sar }}$, while $F_{\text {wap }}$ and $F_{k w}$ showed significantly lower purity compared to that of $F_{\text {sar. }}$. On the other hand, colour and $\mathrm{pH}$ value showed significant differences $(\mathrm{p}<0.05)$ among the four fucoidan samples $\left(F_{\text {sar }}, F_{\text {kar }}, F_{\text {wap }}\right.$, $\left.F_{k w}\right)$. This study also indicated that deodorisation of fucoidan did not significantly affect the antioxidation activities of all four fucoidan samples $\left(F_{\text {sar }}, F_{k a r}, F_{\text {wap }}, F_{k w}\right)$. As a conclusion, it was found that deodorisation of fucoidan using activated carbon method $\left(F_{k a r}\right)$ is a potential method due to its effectiveness in deodorisation and at the same time, exhibited no significant changes towards its purity and antioxidant activities.

Keywords: Antioxidation; deodorisation; fucoidan; physicochemical

\section{PENGenalan}

Rumpai laut adalah alga marin makroskopik yang membentuk sebahagian daripada diet ruji di beberapa negara Asia (Keyimu \& Aminah 2014). Ia telah digunakan dalam penyediaan salad, sup dan juga sebagai makanan berkalori rendah (Sasidharan et al. 2008). Rumpai laut telah dikategorikan kepada tiga kumpulan berdasarkan warna alga iaitu alga merah (Rhadophyta), hijau (Chlorophyta) serta perang (Pheophyta). Ia mengandungi bahan organik dan bukan organik yang memberi manfaat kepada kesihatan manusia (Manivannan et al. 2009). Industri makanan di kebanyakan negara telah menggunakan rumpai 
laut untuk menghasilkan pelbagai produk kerana rumpai laut kaya dengan mineral, vitamin, asid amino perlu, asid lemak perlu, karotenoid, protein, karbohidrat yang tidak dicerna dan serat (Ioannou \& Roussis 2009; Kotnala et al. 2009; Patra et al. 2008).

Selain itu, ekstrak atau polisakarida rumpai laut mempunyai sebatian bioaktif serta farmakologi yang sangat penting seperti alginat, karaginan, agar dan fukoidan yang telah digunakan secara meluas dalam industri perubatan dan farmaseutik (Lim et al. 2014). Sebatian bioaktif dalam ekstrak rumpai laut menghasilkan metabolit sekunder seperti polifenol dan komponen penyerapan ultra ungu yang amat berguna dalam aktiviti biologi (Bansemir et al. 2006; Shevchenko et al. 2007).

Sargassum sp. merupakan salah satu jenis rumpai laut perang yang kaya dengan komponen bioaktif. Ia telah digunakan sebagai bahan makanan untuk manusia, haiwan dan juga baja (Baleta et al. 2011). Komponen polisakarida utama dalam Sargassum sp. adalah fukoidan yang biasa dijumpai dalam matriks ekstraselular Sargassum sp. (Albuquerque et al. 2004). Fukoidan merupakan polisakarida tersulfat yang boleh diperoleh daripada banyak spesies rumpai laut perang. Fukoidan mempunyai residu $\alpha$-L-fukopironosa O-tersulfat yang dihubungkan melalui rantaian $\alpha-(1 \rightarrow 2)-, \alpha-(1 \rightarrow 3)-$ dan/atau $\alpha-(1 \rightarrow 4)$ dengan susunan struktur bercabang (Kim 2015; Lim et al. 2016). Berat molekul fukoidan berbeza daripada 100 sehingga 1600 kDa (Gupta \& Abu-Ghannam 2011). Monomer utama dalam fukoidan adalah fukosa, iaitu salah satu daripada lapan gula biologi perlu. Fukoidan juga mengandungi galaktosa, mannosa, xilosa dan residu asid glukuronik (Bilan et al. 2010). Selain itu, fukoidan mempunyai sifat larut air dan asid (Ruperez et al. 2002).

Banyak kajian mengenai fukoidan telah dijalankan dalam beberapa dekad yang lalu kerana pelbagai aktiviti biologinya. Antaranya termasuklah antikoagulan, antitrombotik, antiviral, antitumor, imunomodulat, antikeradangan, pengurang lemak darah, antioksidan, aktiviti melawan hepatopati, uropati dan nefropati, perlindungan kesan gastrik dan potensi terapeutik dalam pembedahan (Ale 2012; Li et al. 2008; Synytsya et al. 2006). Permintaan yang tinggi daripada pengguna untuk makanan yang diproses secara minimum dan mengandungi bahan pengawet semula jadi, kajian secara mendalam terhadap pengekstrakan antioksidan alternatif semula jadi dan sebatian antimikrob semakin giat dijalankan (AbuGhannam \& Gupta 2010; Ahn et al. 2004; Andarwulan et al. 2010; Apostolidis, Ayaz et al. 2008; Chew et al. 2008; Cox et al. 2008; Rajauria et al. 2010).

Isu kesan karsinogen dan toksik antioksidan sintetik juga telah meningkatkan permintaan terhadap sumber antioksidan semula jadi (Yangthong et al. 2009). Hal ini secara tidak langsung menjadikan fukoidan sebagai salah satu bahan alternatif yang diminati untuk menggantikan bahan bioaktif sintetik.

Walaupun begitu, fukoidan daripada Sargassum sp. (rumpai laut perang) mempunyai bau hanyir yang kuat justeru aplikasinya dalam industri makanan dan kosmetik menjadi terhad (LePape et al. 2002). Komponen utama bau rumpai laut dalam fukoidan mentah adalah alkana (tetradekana, heptadekana dan oktadekana) dan asid lemak (asid heksadekanoik dan asid oleik) (Cho et al. 2011). Oleh yang demikian, kaedah penyahbauan fukoidan yang efektif adalah amat diperlukan bagi membolehkannya diguna sebagai bahan mentah dalam industri makanan, farmaseutik dan kosmeseutik (Park et al. 2010).

Karbon teraktif telah digunakan secara meluas sebagai penjerap berkos rendah yang berfungsi secara efektif dalam mengawal bahan pencemar udara seperti sebatian meruap organik dan nitrogen dioksida (Radaideh et al. 2016). Selain itu, karbon teraktif juga digunakan sebagai penyerap untuk menyingkir warna, rasa dan bau yang tidak diingini dalam loji rawatan air minuman (Srinivasan \& Sorial 2011). Juzuk utama karbon teraktif adalah karbon yang menyumbang sehingga 95\% daripada berat jisim keseluruhan dan atom lain seperti hidrogen, nitogen, sulfur dan oksigen. Ciri karbon teraktif yang mempunyai permukaan berliang seni sesuai sebagai penjerap untuk menyahbau fukoidan (Mohamed 2013). Kajian ini adalah untuk meneroka kaedah yang berkesan mengurangkan bau hanyir fukoidan tanpa membawa kesan negatif terhadap ciri fizikokimia serta aktiviti anti-pengoksidaan. Kaedah yang digunakan untuk penyahbauan ialah karbon teraktif, pengewapan haba dan gabungan kedua-duanya.

\section{BAHAN \& KAEDAH}

\section{PENYEDIAAN SAMPEL}

Sumber rumpai laut perang (Sargassum sp.) telah dibekalkan oleh Marine Ceuticals Sdn. Bhd., Selangor yang memperoleh rumpai laut dari Batam, Indonesia pada April 2015. Rumpai laut telah dibersihkan dan dikeringkan oleh pembekal sebelum kajian. Karbon teraktif jenis arang telah dibeli daripada kedai akuarium yang berdekatan di Bandar Baru Bangi. Fukoidan komersial $\left(\mathrm{F}_{\text {ysk }}\right)$ dengan ketulenan 92\% telah dibekalkan oleh Yaizu Suisankagaku Industry Co. Ltd, Jepun, digunakan untuk analisis ketulenan, manakala fukoidan komersial (ekstrak Fucus vesiculosus) yang berjenama Marinova telah digunakan sebagai rujukan dalam penilaian sensori.

\section{PENGEKSTRAKAN FUKOIDAN}

Sebanyak 20 g (berat kering) sampel rumpai laut telah diperlakukan dengan $200 \mathrm{~mL}$ larutan etanol (85\% v/v) dan direfluks selama 2 jam untuk menyingkirkan pigmen, lemak dan sebatian molekul kecil. Selepas itu, polisakarida telah diekstrak daripada sampel rumpai laut tersebut dengan menggunakan $100 \mathrm{~mL}$ larutan asid asetik (pH3) dengan pengacauan mekanikal pada $455 \pm 5 \mathrm{rpm}$, dalam ketuhar (Memmert $53 \mathrm{~L}$, Jerman) pada suhu $65^{\circ} \mathrm{C}$ selama 3 jam. Larutan telah dipisahkan daripada residu rumpai laut dengan pengemparan (Eppendorf Centrifuge 5810R), pada $12,100 \times g$, selama $5 \mathrm{~min}$. Seterusnya, larutan tersebut telah ditambah dengan $10 \mathrm{~mL}$ larutan 5\% kalsium klorida 
dan dibiarkan pada suhu bilik selama 24 jam. Mendakan kalsium alginat yang terbentuk dipisahkan daripada ekstrak fukoidan melalui turasan (Lim et al. 2017). Sampel kemudiannya didialisis dengan menggunakan tiub Visking selama 24 jam. Pemendakan fukoidan telah dilakukan dengan menggunakan etanol (99\%) pada nisbah 1:4 (larutan sampel:etanol) dan dibiarkan selama 24 jam sebelum dibeku kering menggunakan mesin pembeku kering (Christ Alpha 1-4 LD Plus, Jerman) untuk mendapatkan fukoidan $\left(\mathrm{F}_{\text {sar }}\right)$ daripada Sargassum sp. dalam bentuk pepejal (Yang et al. 2008).

\section{KAEDAH PENYAHBAUAN FUKOIDAN MENGGUNAKAN BUTIRAN KARBON TERAKTIF $\left(\mathrm{F}_{\mathrm{KAR}}\right)$}

$\mathrm{F}_{\text {sar }}$ telah disediakan pada kepekatan $1 \%(\mathrm{w} / \mathrm{v})$ dengan melarutkannya dalam air suling. Larutan yang mengandungi butiran karbon teraktif di dalam bikar dengan nisbah 1:6 (fukoidan:karbon teraktif) telah dikacau secara mekanikal pada suhu bilik, $200 \mathrm{rpm}$, selama 24 jam dengan menggunakan alat penggoncang inkubator (Innova 4080, USA). Seterusnya, butiran karbon teraktif ini telah diasingkan daripada sampel dengan mengempar larutan itu dengan menggunakan mesin pengempar (Eppendorf Centrifuge $5810 \mathrm{R}$ ) pada $12,100 \times \mathrm{g}$ selama $5 \mathrm{~min}$. Sampel kemudiannya ditapis dan dibeku kering menggunakan mesin pembeku kering (Christ Alpha 1-4 LD Plus, Jerman) untuk memperoleh fukoidan $\mathrm{F}_{\mathrm{kar}}$.

\section{KAEDAH PENYAHBAUAN FUKOIDAN MENGGUNAKAN PENGEWAPAN HABA $\left(\mathrm{F}_{\mathrm{WAP}}\right)$}

Larutan $\mathrm{F}_{\text {sar }}(1 \% \mathrm{w} / \mathrm{v})$ telah disediakan dengan menggunakan air suling dan seterusnya diperlakukan dengan pengewapan haba melalui aerasi menggunakan pam udara $(220 \mathrm{~V}, 1.5 \mathrm{~W}$, $1.6 \mathrm{l} / \mathrm{min}$, Aleas, China) pada suhu $50 \pm 5^{\circ} \mathrm{C}$, selama $24 \mathrm{jam}$. Kaedah ini adalah untuk mengewapkan sebatian meruap yang terdapat dalam fukoidan. Sampel kemudiannya dibeku kering menggunakan mesin pembeku kering (Christ Alpha 1-4 LD Plus, Jerman) untuk memperoleh fukoidan $\left(\mathrm{F}_{\text {wap }}\right)$ yang telah dinyahbau.

\section{KAEDAH PENYAHBAUAN FUKOIDAN MENGGUNAKAN GABUNGAN BUTIRAN KARBON TERAKTIF DAN PENGEWAPAN HABA $\left(\mathrm{F}_{\mathrm{KW}}\right)$}

Larutan $\mathrm{F}_{\text {sar }}$ telah disediakan pada kepekatan $1 \%$ $(\mathrm{w} / \mathrm{v})$ dengan menggunakan air suling. Larutan yang mengandungi butiran karbon teraktif di dalam bikar dengan nisbah 1:6 (fukoidan:karbon teraktif) telah dikacau secara mekanikal dengan pada $200 \mathrm{rpm}$, selama 24 jam dengan menggunakan alat penggoncang inkubator (Innova 4080, USA). Seterusnya, butiran karbon teraktif ini telah diasingkan daripada sampel dengan emparan (Eppendorf Centrifuge $5810 \mathrm{R}$ ) pada $12,100 \times \mathrm{g}, 5 \mathrm{~min}$. Larutan yang telah diasingkan telah diperlakukan dengan pengewapan haba melalui aerasi menggunakan pam pada suhu $50 \pm 5^{\circ} \mathrm{C}$, selama 24 jam. Sampel kemudiannya dibeku kering menggunakan mesin pembeku kering (Christ Alpha 1-4 LD Plus, Jerman) untuk memperoleh fukoidan $\mathrm{F}_{\mathrm{kw}}$.

\section{PENILAIAN SENSORI}

Penilaian sensori telah dijalankan untuk menilai keberkesanan kaedah penyahbauan fukoidan. Penilaian dijalankan dengan ujian deskriptif kuantitatif (Stone et al. 1974). Ujian ini hanya melibatkan deria bau sahaja. Seramai 10 orang ahli panel separa terlatih yang terdiri daripada pelajar Sains Makanan, Universiti Kebangsaan Malaysia telah mengambil bahagian dalam penilaian sensori. Penilaian sensori telah dijalankan di Makmal Sensori, Jabatan Sains Makanan, Universiti Kebangsaan Malaysia.

\section{UJIAN DESKRIPTIF KUANTITATIF}

Panel telah diminta untuk menghuraikan bau fukoidan yang diberi dengan perkataan yang sesuai sebagai contoh bau hanyir seperti ikan masin atau tiada bau langsung. Panel diberi sampel fukoidan rujukan yang disediakan daripada fukoidan komersial (50\% ketulenan) dan membuat perbandingan dengan fukoidan Marinova dengan ketulenan $90 \%\left(\mathrm{~F}_{90}\right), \mathrm{F}_{\text {sar }}, \mathrm{F}_{\mathrm{kar}}, \mathrm{F}_{\text {wap }}$ dan $\mathrm{F}_{\mathrm{kw}}$. Kesemua panel telah bersetuju untuk menjadikan bau hanyir sebagai atribut. Seterusnya, panel diminta menilai keamatan bau hanyir dalam kesemua sampel fukoidan dengan berdasarkan skala 1 (tiada bau) hingga 7 (sangat kuat).

Dalam kajian ini, atribut penerimaan keseluruhan juga telah diuji. Kesemua panel diminta menilai tahap penerimaan keseluruhan dengan menggunakan skala 1 (paling tidak suka) hingga 7 (paling suka). Kesemua data yang diperoleh daripada penilaian sensori dihitung dan dinyatakan sebagai min dan sisihan piawai dan dianalisis dengan menggunakan analisis varians (ANOVA) dan kemudiannya dengan ujian julat berganda Duncan (DMRT), menggunakan perisian SPSS versi 22.0. Perbezaan dalam nilai min adalah bererti apabila $p<0.05$.

\section{ANALISIS FIZIKOKIMIA}

Analisis fizikokimia telah dijalankan pada $\mathrm{F}_{\text {sar }}, \mathrm{F}_{\text {kar }}, \mathrm{F}_{\text {wap }}$ dan $\mathrm{F}_{\mathrm{kw}}$ untuk menentukan kesan penyahbauan terhadap ciri fizikokimianya. Analisis yang dijalankan adalah analisis ketulenan, warna dan $\mathrm{pH}$ fukoidan.

Analisis Ketulenan Fukoidan Kempat-empat sampel $\mathrm{F}_{\text {sar }}, \mathrm{F}_{\mathrm{kar}}, \mathrm{F}_{\text {wap }}$ dan $\mathrm{F}_{\mathrm{kw}}$ telah diuji ketulenannya dengan menggunakan kaedah spektrofotometri. Sebanyak 0.02 g sampel fukoidan telah dilarutkan dalam $100 \mathrm{~mL}$ air suling. Larutan piawai fukoidan $\left(\mathrm{F}_{\mathrm{ysk}}\right)$ pula disediakan pada kepekatan 0.002-0.040\% dengan menggunakan air suling sebagai pelarut. Seterusnya, sebanyak $1 \mathrm{~mL}$ alikuot telah dipipet ke dalam tabung uji yang mengandungi $4.5 \mathrm{~mL}$ asid sulfurik yang telah dicairkan $\left(1: 6, \mathrm{H}_{2} \mathrm{O}: \mathrm{H}_{2} \mathrm{SO}_{4}\right)$ dan terendam dalam air sejuk. Selepas disejukkan selama satu minit dalam rendaman air sejuk, tabung uji telah diletakkan dalam rendaman air panas $\left(95^{\circ} \mathrm{C}\right)$ selama 10 minit. Alikuot telah dibiarkan sejuk sehingga suhu bilik sebelum ditambah $0.1 \mathrm{~mL} \mathrm{3 \%} \mathrm{L-sisteina.} \mathrm{Campuran} \mathrm{ini} \mathrm{dikacau}$ dan dibiarkan selama 30 min pada suhu bilik. Serapan 
pada panjang gelombang $396 \mathrm{~nm}$ dan $427 \mathrm{~nm}$ telah dibaca dalam plat 96-telaga menggunakan spektrofotometer mikroplat BioTek Epoch (Vermont, USA). Keluk piawaian fukoidan telah digunakan bagi menentukan ketulenan sampel fukoidan. Replikasi sebanyak tiga kali $(n=3)$ telah digunakan dalam setiap ujian ini (Lim et al. 2014).

Analisis Warna dan pH Warna sampel fukoidan dalam bentuk pepejal telah diukur dengan menggunakan kaedah Hunter Lab iaitu sistem warna $L^{*}$ (kecerahan), $a^{*}$ (kemerahan) dan $b^{*}$ (kekuningan) dengan Minolta Colorimeter (CR 400, Jepun). Nilai $\mathrm{pH}$ sampel fukoidan telah diukur pada fukoidan yang dilarutkan dalam air suling pada kepekatan $0.05 \%$ (w/v), pada suhu bilik, menggunakan meter pH (Model PHM 210-MeterLab).

\section{PENENTUAN AKTIVITI ANTIPENGOKSIDAAN}

Aktiviti antipengoksidaan sampel $\mathrm{F}_{\text {sar }}, \mathrm{F}_{\text {kar }}, \mathrm{F}_{\text {wap }}$ dan $\mathrm{F}_{\mathrm{kw}}$ telah dijalankan untuk menentukan kesan penyahbauan terhadap aktiviti antipengoksidaan fukoidan. Aktiviti antipengoksidaan yang ditentukan adalah aktiviti pemerangkapan radikal bebas 1,1-difenil-2-pikrilhidrazil (DPPH), aktiviti pemerangkapan superoksida anion (SOA) dan aktiviti pemerangkapan radikal hidroksil $(\cdot \mathrm{OH})(\mathrm{Lim}$ et al. 2014).

Aktiviti Pemerangkapan Radikal Bebas (DPPH) Aktitviti pemerangkapan radikal bebas DPPH oleh fukoidan dijalankan dengan menggunakan kaedah Lim et al. (2014). Sampel $F_{\text {sar }}, F_{\text {kar }}, F_{\text {wap }}$ dan $F_{k w}$ telah disediakan pada kepekatan $5 \mathrm{mg} / \mathrm{mL}$. Sebanyak $1 \mathrm{~mL}$ bagi setiap sampel fukoidan dicampur dengan $2.9 \mathrm{~mL} 0.15 \mathrm{mM}$ DPPH (0.0059 $\mathrm{g}$ dalam $100 \mathrm{~mL}$ larutan metanol). Sampel kawalan tanpa DPPH telah disediakan dengan mencampur $1 \mathrm{~mL}$ sampel dengan $2.9 \mathrm{~mL}$ metanol. Manakala DPPH pengosong telah disediakan dengan pencampuran $2.9 \mathrm{~mL} 0.15 \mathrm{mM}$ DPPH (dalam larutan metanol) dengan $1 \mathrm{~mL}$ air suling. Selepas pengeraman dalam gelap selama $30 \mathrm{~min}$, penyerapan pada gelombang $517 \mathrm{~nm}$ diukur dengan menggunakan spektrofotometer mikroplat BioTek Epoch (Vermont, USA). Ujian DPPH diulang sebanyak tiga kali $(n=3)$. Kadar pemerangkapan radikal bebas dihitung dengan menggunakan formula seperti berikut:

$\begin{aligned} & \text { \% Aktviti pemerangkapan } \\ & \text { radikal bebas DPPH }\end{aligned}=\left[\mathrm{A}_{\mathrm{B}}-\left(\mathrm{A}_{\mathrm{S}}-\mathrm{A}_{\mathrm{C}}\right)\right] / \mathrm{A}_{\mathrm{B}}$

dengan $A_{B}$ ialah penyerapan DPPH pengosong; $A_{S}$ ialah penyerapan DPPH dengan sampel; dan $\mathrm{A}_{\mathrm{C}}$ ialah penyerapan sampel tanpa DPPH.

Aktiviti Pemerangkapan Superoksida Anion(SOA) Aktitviti pemerangkapan superoksida anion telah ditentukan dengan menguji perencatan auto-pengoksidaan piragalol. Sampel $\mathrm{F}_{\text {sar }}, \mathrm{F}_{\mathrm{kar}}, \mathrm{F}_{\text {wap }}$, dan $\mathrm{F}_{\mathrm{kw}}$ telah disediakan pada kepekatan $2 \mathrm{mg} / \mathrm{mL}$. Sampel $(0.3 \mathrm{~mL})$ telah dicampur dengan 2.6 $\mathrm{mL}$ larutan penimbal fosfat (50 mM, pH 8.24) dan $90 \mu \mathrm{L}$ larutan $3 \mathrm{mM}$ piragalol (dilarutkan dalam $10 \mathrm{mM} \mathrm{HCl}$ ). Serapan telah ditentukan pada panjang gelombang $325 \mathrm{~nm}$ dengan menggunakan spektrofotometer mikroplat BioTek Epoch (Vermont, USA) dengan penyerapan telah direkod selang setiap satu minit selama 10 min. Replikasi $(n=3)$ telah dijalankan bagi setiap ujian (Heo et al. 2005; Lim at el. 2014). Peratusan aktiviti pemerangkapan superoksida anion telah dihitung dengan menggunakan formula seperti berikut:

$$
\begin{aligned}
& \text { Kadar pemerangkapan } \\
& \operatorname{SOA}(\%)
\end{aligned}=\left[1-\left(\mathrm{A}_{2}-\mathrm{A}_{1}\right) / \mathrm{A}_{0}\right] \times 100
$$

dengan $A_{1}$ ialah penyerapan sampel pada 0 min; $A_{2}$ ialah penyerapan sampel pada $10 \mathrm{~min}$; dan $\mathrm{A}_{0}$ ialah kadar autopengoksidaan piragalol untuk pengosong.

Kadar Pemerangkapan Radikal Hidroksil $(\bullet \mathrm{OH})$ Sampel $\mathrm{F}_{\text {sar }}, \mathrm{F}_{\mathrm{kar}}, \mathrm{F}_{\mathrm{wa}} \mathrm{p}$, dan $\mathrm{F}_{\mathrm{kw}}$ pada kepekatan $2 \mathrm{mg} / \mathrm{mL}$ telah disediakan. Sebanyak $0.5 \mathrm{~mL}$ larutan ferus sulfat $\left(\mathrm{FeSO}_{4}\right)$ pada $9 \mathrm{mM}$ telah ditambah dengan $1.0 \mathrm{~mL}$ larutan 8.8 $\mathrm{mM}$ hidrogen peroksida $\left(\mathrm{H}_{2} \mathrm{O}_{2}\right)$ (ketulenan $35 \%, \mathrm{HmbG}$ Chemicals). Campuran tersebut telah ditambah ke dalam sampel fukoidan $(1.0 \mathrm{~mL})$ yang telah disediakan sebelum ditambah $0.2 \mathrm{~mL}$ larutan $9 \mathrm{mM}$ asid salisilik. Satu set larutan tindak balas berasingan telah disediakan seperti sebelum ini tetapi tanpa penambahan larutan asid salisilik. Campuran tersebut telah dibiarkan pada suhu $37^{\circ} \mathrm{C}$ selama 1 jam. Serapan pada panjang gelombang $510 \mathrm{~nm}$ ditentukan dengan menggunakan spektrofotometer mikroplat BioTek Epoch (Vermont, USA). Aktiviti pemerangkapan radikal hidroksil sampel telah ditentukan sebanyak tiga replikasi $(n=3)$ dan aktiviti dihitung dengan menggunakan formula seperti berikut:

$\begin{aligned} & \text { Kadar pemerangkapan } \\ & \cdot \mathrm{OH}(\%)\end{aligned}=\left[1-\left\{\left(\mathrm{A}_{1}-\mathrm{A}_{2}\right) / \mathrm{A}_{0}\right\}\right] \times 100$

dengan $\mathrm{A}_{0}$ ialah penyerapan pengosong; $\mathrm{A}_{1}$ ialah penyerapan tindak balas sampel dengan asid salisilik; dan $\mathrm{A}_{2}$ ialah penyerapan tindak balas sampel tanpa asid salisilik.

\section{ANALISIS STATISTIK}

Data dihitung dan dianalisis dengan menggunakan analisis varians (ANOVA) dan ujian julat berganda (DMRT) menggunakan perisian SPSS versi 22.0. Kesemua analisis dijalankan secara triplikasi, $n=3$. Penentuan sama ada perbezaan yang berlaku adalah bererti atau tidak ditentukan pada aras signifikan $95 \%(p<0.05)$.

\section{KEPUTUSAN DAN PERBINCANGAN}

\section{KEBERKESANAN PENYAHBAUAN FUKOIDAN}

Penghiduan pertama sering mempunyai pengaruh yang besar terhadap penerimaan keseluruhan produk. Bau hanyir fukoidan yang tidak menyenangkan telah menyebabkan 
kurang sambutan terhadapnya. Oleh itu, penilaian sensori dijalankan untuk mengkaji kesan penyahbauan fukoidan terhadap keamatan bau hanyir dan penerimaan keseluruhan dalam sampel fukoidan.

Keberkesanan penyahbauan fukoidan melalui penilaian sensori adalah seperti yang ditunjukkan dalam Rajah 1. Keamatan bau hanyir dengan min skor yang paling rendah secara signifikan $(p<0.05)$ ditunjukkan oleh $\mathrm{F}_{\mathrm{kar}}$ berbanding $\mathrm{F}_{\text {sar }}$ (Rajah 1(a)). Keamatan bau sampel $\mathrm{F}_{\text {wap }}$ dan $\mathrm{F}_{\mathrm{kw}}$ tidak menunjukkan perbezaan dengan keamatan bau sampel $\mathrm{F}_{\text {sar }}$. Kaedah perlakuan pengewapan haba dan karbon teraktif tidak menunjukkan penurunan keamatan yang besar berbanding $\mathrm{F}_{\text {kar }}$. Oleh yang demikan, kaedah karbon teraktif adalah paling berkesan. Kaedah perlakuan karbon teraktif dan pengewapan sering digunakan dalam rawatan air untuk menyahbau air (Khalili et al. 2000). Karbon teraktif merupakan bahan yang mempunyai permukaan ruang seni yang membolehkannya menjerap pelbagai jenis molekul, seperti gas, ion dan molekul kecil, termasuk sebatian meruap yang memberikan bau hanyir. Oleh itu, perlakuan sampel fukoidan dengan karbon teraktif telah mengurangkan keamatan bau hanyir melalui penjerapan sebatian-sebatian meruap yang memberikan bau hanyir. Pengewapan haba pula didapati kurang berkesan, yang menunjukkan bahawa sebatian meruap tidak dapat disingkirkan melalui kaedah ini. Terdapat kemungkinan terdapat tindak balas pada sebatian meruap apabila didedahkan dengan oksigen dan haba, tetapi tidak dapat dipisahkan daripada fukoidan.

Keberkesanan penyahbauan $\mathrm{F}_{\mathrm{kar}}$ dimanifestasi oleh penerimaan keseluruhan yang tertinggi secara signifikan $(p<0.05)$, iaitu min skor sebanyak 5.2 \pm 1.62 (Rajah 1(b)). Sampel $\mathrm{F}_{\text {wap }}$ dan $\mathrm{F}_{\mathrm{kw}}$ pula tidak menunjukkan perbezaan signifikan $(p>0.05)$ berbanding $\mathrm{F}_{\text {sar }}$. Keamatan bau hanyir dalam fukoidan memberi kesan terhadap tahap penerimaan keseluruhan fukoidan dengan bau hanyir fukoidan yang rendah meningkatkan tahap penerimaan keseluruhan.

\section{CIRI FIZIKOKIMIA}

Ketulenan Ketulenan fukoidan adalah sangat penting dalam kajian ciri-ciri biologi fukoidan (Ermakova et al. 2015). Ini kerana, ketulenan fukoidan yang tinggi akan menunjukkan aktiviti biologi yang lebih tinggi. Namun begitu, pengekstrakan fukoidan pada ketulenan yang tinggi adalah agak rumit kerana pembentukan kompleks yang kuat antara polisakarida dan bendasing seperti polifenol yang tidak boleh dihilangkan tanpa mengubah integriti molekul fukoidan (Costa et al. 2011; Hu et al. 2010). Selain itu, alginat juga akan terekstrak bersama semasa pengekstrakan fukoidan (Lim et al. 2017).

Ketulenan sampel $\mathrm{F}_{\mathrm{kar}}$ dan $\mathrm{F}_{\text {sar }}$ tidak berbeza secara signifikan $(p>0.05)$ manakala ketulenan sampel $\mathrm{F}_{\text {wap }}$ dan $\mathrm{F}_{\mathrm{kw}}$ adalah lebih rendah secara signifikan $(p<0.05)$ berbanding $\mathrm{F}_{\text {sar }}$ (Rajah 2). Ini menunjukkan bahawa karbon teraktif telah berjaya menyahbau fukoidan tanpa mengubah ketulenan fukoidan, berbanding kaedah pengewapan haba. Karbon teraktif biasanya digunakan sebagai penapis bau a)

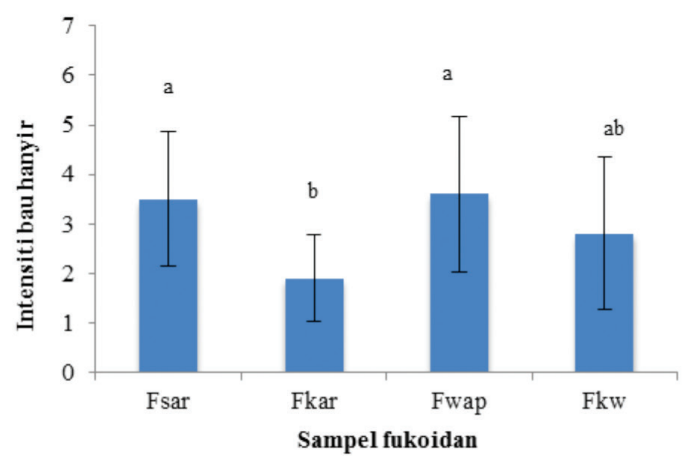

b)

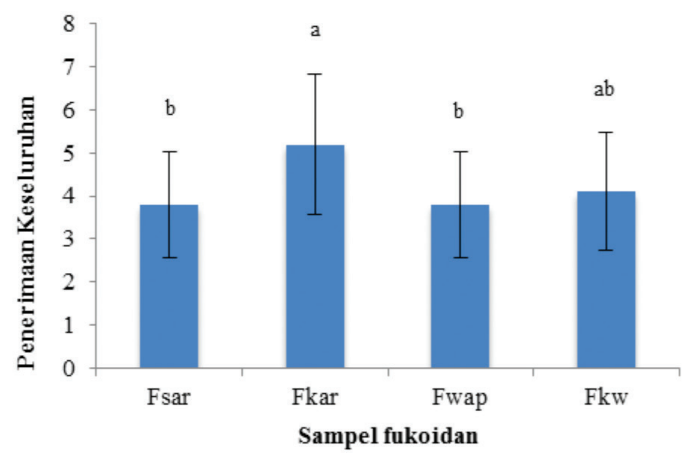

a-b abjad berbeza pada lajur yang sama menunjukkan perbezaan signifikan $(p<0.05)$

RAJAH 1. a) Keamatan bau hanyir fukoidan mentah $\left(\mathrm{F}_{\text {sar }}\right)$ dan fukoidan dinyahbau $\left(\mathrm{F}_{\mathrm{kar}}, \mathrm{F}_{\text {wap }} \& \mathrm{~F}_{\mathrm{kw}}\right)$, b) Penerimaan keseluruhan fukoidan mentah $\left(\mathrm{F}_{\mathrm{sar}}\right)$ dan fukoidan dinyahbau $\left(\mathrm{F}_{\mathrm{kar}}, \mathrm{F}_{\text {wap }} \& \mathrm{~F}_{\mathrm{kw}}\right)(n=10)$

dengan komponen meruap dijerap melalui luas permukaan karbon teraktif yang besar. Penjerapan komponen meruap dalam karbon teraktif biasanya melibatkan proses fizikal sahaja tanpa pembentukan ikatan kimia (Marsh \& Reinoso 2006). Penjerapan komponen meruap dengan karbon teraktif juga mengurangkan benda asing seperti pigmen warna dalam fukoidan. Keadaan ini telah menyebabkan nilai ketulenan sampel $\mathrm{F}_{\mathrm{kar}}$ tidak menurun berbanding $\mathrm{F}_{\text {sar }}$ yang tidak dinyahbau.

Berbeza dengan mekanisme penjerapan karbon teraktif, konsep pengewapan haba pula merupakan satu sistem yang memberi gas atmosfera ke dalam larutan bagi menyingkirkan bahan organik meruap (AWWA 2011). Pemberian gas atmosfera secara berterusan turut meningkatkan kandungan gas oksigen dalam larutan sampel fukoidan dan telah menyebabkan pengoksidaan komponen polifenol yang mudah dinyahasli pada suhu yang sederhana tinggi (Miralai et al. 2008; Sharma 2013). Menurut Indrawati (2015), fukoidan mempunyai ikatan yang kuat dengan polifenol dan susah dipisahkan antara satu sama lain. Oleh itu, pengoksidaan polifenol telah memberi kesan kepada struktur fukoidan yang mempunyai ikatan kuat dengannya. Proses penyahbauan dengan penggunaan pengewapan haba menyebabkan kehilangan 


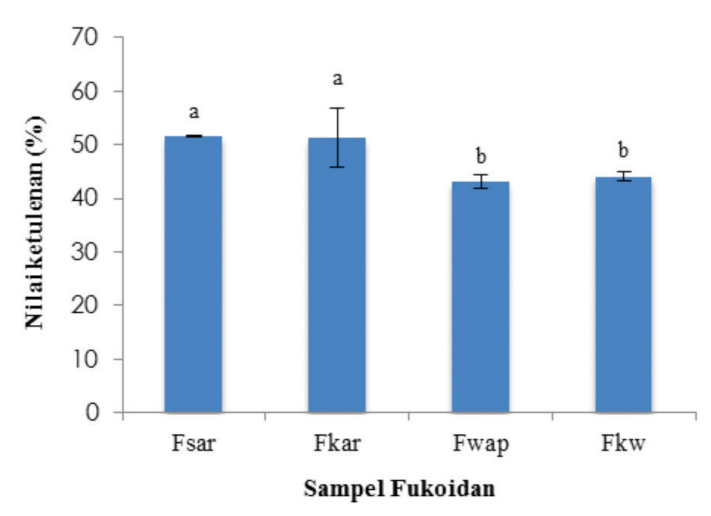

a-b abjad berbeza menunjukkan perbezaan signifikan $(p<0.05)$.

RAJAH 2. Nilai ketulenan (\%) sampel fukoidan mentah dan fukoidan yang dinyahbau dengan kaedah yang berbeza. Nilai ketulenan adalah nilai min \pm daripada triplikasi $(n=3)$

fukoidan tulen dalam sampel dan menyebabkan penurunan nilai ketulenan sampel fukoidan $\mathrm{F}_{\text {wap }}$ dan $\mathrm{F}_{\mathrm{kw}}$

Warna Nilai purata $\mathrm{L}^{*}, \mathrm{a}^{*}$ dan $\mathrm{b}^{*}$ bagi sampel $\mathrm{F}_{\text {sar }}$ dan fukoidan yang dinyahbau dengan kaedah berlainan $\left(\mathrm{F}_{\mathrm{kar}}\right.$, $\mathrm{F}_{\text {wap }}$, dan $\mathrm{F}_{\mathrm{kw}}$ ) adalah seperti yang dipaparkan dalam Jadual 1. Didapati warna $F_{\text {sar }}$ berubah secara signifikan apabila dinyahbau. Didapati $\mathrm{F}_{\mathrm{kar}}$ mempunyai kecerahan, darjah kemerhan dan kekuningan yang lebih rendah secara signifikan $(p<0.05)$ berbanding $\mathrm{F}_{\text {sar }}$. Sementara itu, $\mathrm{F}_{\text {wap }}$ pula menunjukkan kecerahan dan darjah kekuningan yang lebih tinggi secara signifikan berbanding $\mathrm{F}_{\mathrm{sar}}$, manakala $\mathrm{F}_{\mathrm{kw}}$ hanya berbeza secara signifikan $(p<0.05)$ berbanding $\mathrm{F}_{\mathrm{sar}}$ daripada segi darjah kekuningan yang lebih tinggi.

Menurut Calvo dan Casero (2008), karbon teraktif digunakan untuk merawat produk minuman untuk mengawal dan membetulkan warna produk dengan menjadikan warnanya lebih konsisten. Selain itu, penjerapan sebatian kecil pada karbon teraktif juga menyingkirkan benda asing dan mengubah warna pada fukoidan. Hal ini menyebabkan berlaku perubahan pada darjah kecerahan dan kemerahan setelah fukoidan diperlakukan dengan karbon teraktif. Sementara itu, seperti yang dilaporkan oleh Doble dan Kumar (2005), pengewapan haba pada air buangan menyebabkan penyahwarnaan akibat pengurangan jumlah karbon organik dan menjadikan air lebih jernih warnanya. Hal ini menyebabkan sampel $\mathrm{F}_{\text {wap }}$ yang telah dinyahbau dengan pengewapan haba menjadi ternyahwarna dan menyebabkan warnanya menjadi lebih cerah berbanding sampel $\mathrm{F}_{\mathrm{sar}}$ dan $\mathrm{F}_{\mathrm{kar}}$. Hal ini adalah konsisten dengan keputusan daripada analisis ketulenan fukoidan dengan $\mathrm{F}_{\text {wap }}$ dan $\mathrm{F}_{\mathrm{kw}}$ mempunyai ketulenan yang lebih rendah berbanding $\mathrm{F}_{\text {sar }}$ dan $\mathrm{F}_{\text {kar }}$. Fukoidan pada dasarnya adalah berwarna perang dan ketulenan yang lebih tinggi akan menyerlahkan lagi warna keperangan yang adalah lebih gelap (darjah kecerahan yang lebih rendah pada $\mathrm{F}_{\mathrm{kar}}$ ).

Nilai $\mathrm{pH}$ Keputusan pada Jadual 2 menunjukkan nilai $\mathrm{pH}$ antara sampel $\mathrm{F}_{\text {sar }}, \mathrm{F}_{\mathrm{kar}}, \mathrm{F}_{\text {wap }}$, dan $\mathrm{F}_{\mathrm{kw}}$. Didapati terdapat perbezaan signifikan $(p<0.05)$ antara sampel $\mathrm{F}_{\text {sar }}$ dengan sampel $\mathrm{F}_{\mathrm{kar}}, \mathrm{F}_{\mathrm{wap}}$, dan $\mathrm{F}_{\mathrm{kw}}$. Sampel $\mathrm{F}_{\mathrm{kar}}$ yang menunjukkan peningkatan nilai $\mathrm{pH}$ secara signifikan berbanding $\mathrm{F}_{\text {sar' }}$, manakala sampel $\mathrm{F}_{\text {wap }}$ dan $\mathrm{F}_{\mathrm{kw}}$ menunjukkan penurunan $\mathrm{pH}$ secara signifikan berbanding $\mathrm{F}_{\text {sar }}$. Penggunaan karbon teraktif berkemungkinan telah menjerap dan menyingkirkan sebatian polifenol yang sedikit berasid dengan peningkatan nilai $\mathrm{pH}$ pada $\mathrm{F}_{\mathrm{kar}}$ telah diperhatikan. Antara kumpulan sebatian polifenol yang dilaporkan hadir dalam rumpai laut perang adalah florotanin, bromofenol, meroditerpenoid dan kolpol (Freile-Pelegrín \& Robledo 2014). Sementara itu, penurunan nilai $\mathrm{pH}$ selepas dinyahbau dengan menggunakan pengewapan haba adalah disebabkan oleh keterlarutan karbon dioksida

JADUAL 1. Nilai L*, a* dan $b^{*}$ sampel fukoidan mentah dan sampel fukoidan yang dinyahbau dengan kaedah yang berbeza $(n=3)$

\begin{tabular}{cccc}
\hline Sampel & $\mathrm{L}^{*}$ & $\mathrm{a}^{*}$ & $\mathrm{~b}^{*}$ \\
\hline $\mathrm{F}_{\text {sar }}$ & $60.58 \pm 0.07^{\mathrm{b}}$ & $6.87 \pm 0.03^{\mathrm{a}}$ & $16.38 \pm 0.03^{\mathrm{b}}$ \\
$\mathrm{F}_{\text {kar }}$ & $56.49 \pm 1.17^{\mathrm{c}}$ & $5.34 \pm 0.17^{\mathrm{c}}$ & $15.21 \pm 0.09^{\mathrm{c}}$ \\
$\mathrm{F}_{\text {wap }}$ & $62.95 \pm 1.54^{\mathrm{a}}$ & $6.68 \pm 0.17^{\mathrm{ab}}$ & $17.28 \pm 0.20^{\mathrm{a}}$ \\
$\mathrm{F}_{\text {kw }}$ & $60.16 \pm 0.51^{\mathrm{b}}$ & $6.44 \pm 0.20^{\mathrm{b}}$ & $17.27 \pm 0.18^{\mathrm{a}}$ \\
\hline
\end{tabular}

${ }^{a-c}$ abjad berbeza pada lajur yang sama menunjukkan perbezaan signifikan $(p<0.05)$

JADUAL 2. Nilai pH sampel fukoidan mentah dan fukoidan yang dinyahbau dengan kaedah yang berbeza $(n=3)$

\begin{tabular}{cc}
\hline Sampel & nilai $\mathrm{pH}$ \\
\hline $\mathrm{F}_{\text {sar }}$ & $7.26 \pm 0.03^{\mathrm{b}}$ \\
$\mathrm{F}_{\mathrm{kar}}$ & $7.57 \pm 0.04^{\mathrm{a}}$ \\
$\mathrm{F}_{\text {wap }}$ & $6.91 \pm 0.03^{\mathrm{c}}$ \\
$\mathrm{F}_{\mathrm{kw}}$ & $6.84 \pm 0.03^{\mathrm{d}}$ \\
\hline a-d abjad berbeza pada
\end{tabular}

a-d abjad berbeza pada lajur yang sama menunjukkan perbezaan signifikan $(p<0.05)$ 
dalam sampel yang menghasilkan asid karbonik. Oleh itu, sampel $\mathrm{F}_{\text {wap }}$ dan $\mathrm{F}_{\mathrm{kw}}$ mempunyai $\mathrm{pH}$ yang lebih rendah secara signifikan berbanding $\mathrm{F}_{\text {sar }}$.

\section{AKTIVITI ANTIPENGOKSIDAAN}

Ujian Pemerangkapan Radikal Bebas DPPH Ujian pemerangkapan radikal bebas DPPH adalah satu kaedah untuk mengukur kemampuan ekstrak untuk memerangkap radikal bebas melalui pertukaran DPPH kepada bentuk DPPH-H yang stabil setelah penerimaan elektron atau radikal hidrogen (Mohd Fadzelly et al. 2015). Rajah 3(a) menunjukkan tiada perbezaan signifikan $(p>0.05)$ dalam peratusan pemerangkapan radikal bebas DPPH oleh keempat-empat sampel fukoidan $\left(\mathrm{F}_{\text {sar }}, \mathrm{F}_{\mathrm{kar}}, \mathrm{F}_{\text {wap }}\right.$ dan $\left.\mathrm{F}_{\mathrm{kw}}\right)$. Ini menunjukkan aktiviti pemerangkapan radikal bebas DPPH fukoidan tidak dipengaruhi oleh kaedah penyahbauan.

Park et al. (2005) pernah melaporkan bahawa aktiviti pemerangkapan radikal berhubung kait dengan kandungan ekstrak fukoidan dan semakin tinggi kandungan ekstrak fukoidan semakin tinggi aktiviti pemerangkapan radikal. Kenyataan ini telah menunjukkan bahawa perbezaan peratusan pemerangkapan radikal bebas DPPH mungkin dipengaruhi oleh faktor nilai ketulenan sampel fukoidan. Perbezaan ketulenan antara $\mathrm{F}_{\text {sar }}, \mathrm{F}_{\mathrm{kar}}, \mathrm{F}_{\text {wap }}$ dan $\mathrm{F}_{\mathrm{kw}}$ adalah kecil dan tidak menyebabkan perbezaan signifikan dalam aktiviti pemerangkapan radikal bebas DPPH oleh fukoidan daripada Sargassum sp.

Aktiviti Pemerangkapan Superoksida Anion (SOA) Pemerangkapan superoksida anion dalam sampel fukoidan $\left(\mathrm{F}_{\mathrm{sar}}, \mathrm{F}_{\mathrm{kar}}, \mathrm{F}_{\mathrm{wap}}, \mathrm{F}_{\mathrm{kw}}\right)$ juga tidak berbeza dengan signifikan $(p>0.05)$ seperti yang ditunjukkan pada Rajah 3(b). Ini menunjukkan bahawa perlakuan penyahbauan terhadap fukoidan daripada Sargassum sp. tidak menyebabkan perubahan pada aktiviti pemerangkapan superoksida anion dalam fukoidan. Sebaliknya, Imbs et al. (2015) melaporkan penulenan fukoidan daripada bendasing seperti polifenol menyebabkan penurunan aktiviti antipengoksidaan serta aktiviti antibakteria. Namun, aktiviti pemerangkapan SOA adalah aktiviti antioksidan sekunder, yang aktiviti antioksidannya adalah daripada fukoidan dan bukannya sebatian polifenol yang hadir dengan sebatian polifenol memberikan aktiviti antioksidan primer. Oleh itu, pengurangan sebatian polifenol semasa proses penyahbauan tidak mempengaruhi aktiviti pemerangkapan SOA oleh sampel fukoidan.

Kadar Pemerangkapan Radikal Hidroksil $(\bullet \mathrm{OH})$ Kaedah pemerangkapan radikal hidroksil juga tidak berbeza dengan a)

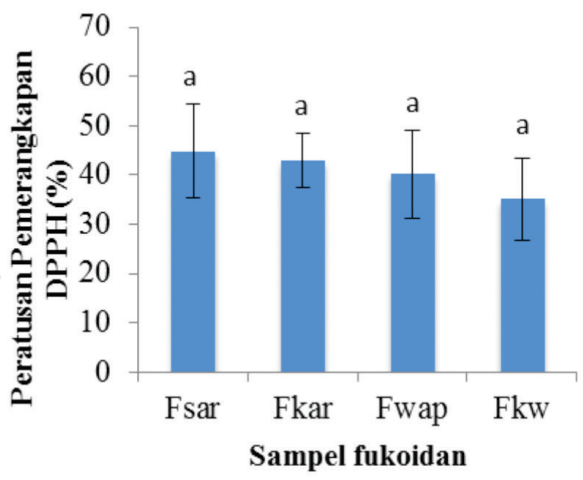

b)

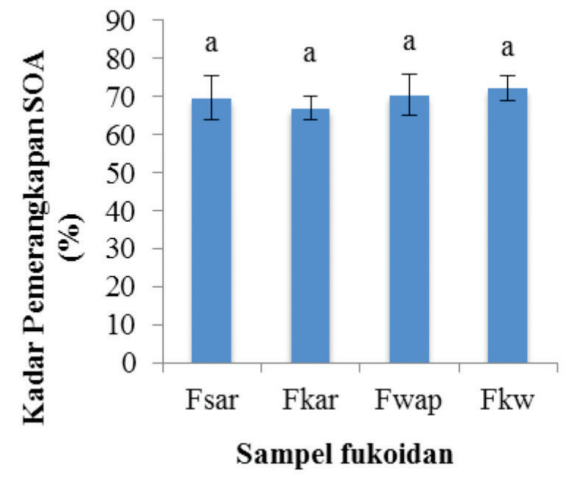

c)

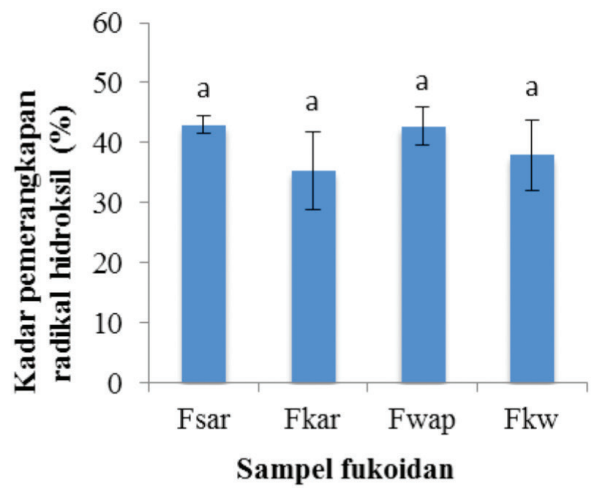

tiada perbezaan signifikan $(p<0.05)$ antara semua sampel

RAJAH 3. a) Nilai peratusan pemerangkapan radikal bebas (DPPH) dalam sampel fukoidan $\left(\mathrm{F}_{\text {sar, }}, \mathrm{F}_{\mathrm{kar}}, \mathrm{F}_{\mathrm{wap}}\right.$, $\left.\mathrm{F}_{\mathrm{kw}}\right)$, b) Nilai peratusan kadar pemerangkapan SOA dalam sampel fukoidan $\left(\mathrm{F}_{\mathrm{sar}}, \mathrm{F}_{\mathrm{kar}}, \mathrm{F}_{\mathrm{wan}}, \mathrm{F}_{\mathrm{kw}}\right)$ dan $\left.\mathrm{c}\right)$ Nilai peratusan kadar pemerangkapan radikal hidroksil dalam sampel fukoidan $\left(\mathrm{F}_{\text {sar, }}, \mathrm{F}_{\text {kar }}, \mathrm{F}_{\text {wap }}, \mathrm{F}_{\mathrm{kw}}\right)(n=3)$ 
signifikan $(p>0.05)$ bagi keempat-empat sampel fukoidan $\left(\mathrm{F}_{\text {sar }}, \mathrm{F}_{\mathrm{kar}}, \mathrm{F}_{\text {wap }}, \mathrm{F}_{\mathrm{kw}}\right)$, seperti yang ditunjukkan pada Rajah 3(c). Ini menunjukkan bahawa perlakuan penyahbauan terhadap fukoidan daripada Sargassum sp. tidak menyebabkan perubahan pada aktiviti pemerangkapan radikal hidroksil dalam fukoidan. Lim et al. (2014) juga melaporkan fukoidan yang diekstrak daripada Sargassum binderi Malaysia mempunyai aktiviti pemerangkapan radikal hidroksil yang tinggi, dan ia adalah lebih tinggi berbanding antioksidan sintetik hidroksitoluena terbutil (BHT).

Secara keseluruhannya, fukoidan yang diekstrak daripada Sargassum sp. tidak menunjukkan perbezaan aktiviti antipengoksidaan yang signifikan selepas diperlakukan dengan proses penyahbauan.

\section{KESIMPULAN}

Kaedah penyahbauan fukoidan menggunakan karbon teraktif $\left(\mathrm{F}_{\mathrm{kar}}\right)$ menunjukkan keputusan yang menggalakkan, berupaya menurunkan keamatan bau hanyir dan meningkatkan penerimaan keseluruhan fukoidan. Pada masa yang sama, kaedah ini juga tidak menyebabkan perubahan pada nilai ketulenan dan aktiviti antipengoksidaan fukoidan. Oleh itu, kaedah penyahbauan fukoidan menggunakan karbon teraktif berpotensi untuk diaplikasikan, supaya penggunaan fukoidan sebagai ingredien dan bahan makanan dapat ditingkatkan.

\section{PENGHARGAAN}

Kajian ini telah dijalankan menggunakan geran penyelidikan GGPM-2015-025 dan GUP-2017-052 daripada Universiti Kebangsaan Malaysia. Setinggi-tinggi penghargaan kepada Fakulti Sains dan Teknologi, Universiti Kebangsaan Malaysia yang telah menyediakan segala kemudahan makmal bagi menjalankan kajian.

\section{RUJUKAN}

Ahn, M.J., Yoon, K.D., Min, S.Y., Lee, J.S., Kim, J.H., Kim, T.G., Kim, T.G., Kim, S.H., Kim, N.G., Huh, H. \& Kim, J.W. 2004. Inhibition of HIV-1 reverse transcriptase and protease by phlorotannins from the brown alga Ecklonia cava. Biological and Pharmaceutical Bulletin 27: 544-547.

Albuquerque, I.R.L., Queiroz, K.C.S., Alves, L.G., Santos, E.A., Leite, E.L. \& Rocha, H.A.O. 2004. Heterofucans from Dictyota menstrualis have anticoagulant activity. Brazilian Journal of Medical and Biological Research 37: 167-171.

Ale, M.T. 2012. Fucose-containing sulphated polysaccharides from brown seaweed: Extraction technolgy and bioactivity assessment. Technical University of Denmark (Unpublished).

Andarwulan, N., Batari, R., Sandrasari, D.A., Bolling, B. \& Wijaya, H. 2010. Flavonoid content and antioxidant activity of vegetables from Indonesia. Food Chemistry 121: 12311235.

Apostolidis, E., Kwon, Y.I. \& Shetty, K. 2008. Inhibition of Listeria monocytogenes by oregano, cranberry and sodium lactate combination in broth and cooked ground beef systems and likely mode of action through proline metabolism. International Journal of Food Microbiology 128: 317-324.
AWWA. 2011. Water Treatment. USA: American Water Works Association.

Ayaz, F.A., Ayaz, S.H., Alpay-Karaoglu, S., Grúz, J., Valentová, K., Ulrichová, J. \& Strnad, M. 2008. Phenolic acid contents of kale (Brassica oleraceae L. var. acephala DC.) extracts and their antioxidant and antibacterial activities. Food Chemistry 107: $19-25$

Baleta, F.N., Laureta, L.V., Apines-Amar, M.J.S., Padilla, P.I. \& Quinitio, G.F. 2011. Biological activity of extracts of Sargassum oligocystum (Magnaye) against aquaculture pathogenic bacteria. The Israeli Journal of Aquaculture 63: 67-71.

Bansemir, A., Blume, M., Schroder, S. \& Lindiquist, U. 2006. Screening of cultivated seaweeds for antibacterial acivity against fish pathogenic bacteria. Aquaculture 252: 79-84.

Bilan, M.I., Grachev, A.A., Shashkov, A.S., Kelly, M., Sanderson, C.J., Nifantiev, N.E. \& Usov, A.I. 2010. Further studies on the composition and structure of a fucoidan preparation from the brown alga Saccharina latissima. Carbohydrate Research 345(14): 2038-2047.

Calvo, L. \& Cosero, M.J. 2008. Concentration of bioactive compounds by adsorption/desorption. Dlm. Extracting Bioactive Compounds for Food Products: Theory and Applications, disunting oleh Meireles, M.A.A. USA: CRC Press. hlm. 404-434.

Chew, Y.L., Lim, Y.Y., Omar, M.\& Khoo, K.S. 2008. Antioxidant activity of three edible seaweeds from two areas in South East Asia. LWT - Food Science and Technology 41: 1067-1072.

Cho, E.H., Park, K.H., Kim, S.Y., Oh, C.S., Bang, S.I. \& Chae, H.J. 2011. Process development for deordorization of fucoidan using a combined method of solvent extraction and spray drying. Korean Society for Biotechnology and Bioengineering Journal 26(1): 49-56.

Costa, L.S., Fidelis, G.P., Telles, C.B., Dantas-Santos, N., Camara, R.B., Cordeiro, L.S., Almeida-Lima, J., MeloSilveira, R.F., Oliveira, R.M., Albuquerque, I.R., Andrade, G.P. \& Roche, H.A. 2011. Antioxidant and antiproliferative activities of heterofucans from the seaweed Sargassum filipendula. Marine Drugs 9(6): 952-966.

Cox, S., Abu-Ghannam, N. \& Gupta, S. 2010. An assessment of the antioxidant and antimicrobial activity of six species of edible Irish seaweeds. International Food Research Journal 17: 205-220.

Doble, M. \& Kumar, A. 2005. Biotreatment of Industrial. United Kingdom: Butterworth-Heinemann.

Ermakova, S., Kusaykim, M., Trincone, A. \& Tatiana, Z. 2015. Are multifunctional marine polysaccharides a myth or reality? Dlm. Marine Biomolecules, disunting oleh Trincone, A., Kusaykim, M. \& Ermakova, S. Switzerland: Fronties Media. hlm. 94-97.

Freile-Pelegrín, Y. \& Robledo, D. 2014. Bioactive phenolic compounds from algae. Dlm. Bioactive Compounds from Marine Foods: Plant and Animal Sources, disunting oleh Hernández-Ledesma, B. \& Herrero, M. London: John Wiley \& Sons, Ltd.

Gupta, S. \& Abu-Ghannam, N. 2011. Bioactive potential and possible health effects of edible brown seaweeds. Trends Food Science and Technology 22: 315-326.

Heo, S.J., Park, E.J., Lee, K.W. \& Jeon, Y.J. 2005. Antioxidant activities of enzymatic extracts from brown seaweeds. Biosource Technology 96: 1613-1623. 
Hu, T., Liu, D., Chen, Y., Wu, J. \& Wang, S. 2010 Antioxidant activities of sulfated polysaccharide fraction extracted from Undaria pinnitafida in vitro. International Journal of Biological Macromolecules 46: 193-198.

Imbs, T.I., Skriptsova, A.V. \& Zvyagintseva, T.N. 2015. Antioxidant activity of fucose containing sulphated polysaccharides obtained from Fucus evanescens by different extraction methods. Journal of Applied Psychology 27: 545-553.

Indrawati, R., Sukowijoyo, H., Indratmoko, Wijayanti, R.D.E.\& Limantara, L. 2015. Encapsulation of brown seaweed pigment by freeaing drying: Characterization and its stability during storage. Procedia Chemistry 14: 353-360.

Ioannou, E. \& Roussis, V. 2009. Natural products from seaweeds. Dlm. Plant-derived Natural Products, disunting oleh Osbourn, A. \& Lanzotti, V. New York: Springer. hlm. 51-81.

Keyimu,X.G.\& Aminah,A. 2014. Elimination of seaweed odour and its effect on antioxidant activity. American Institute of Physics Publishing 1614: 339-403.

Khalili, N.R., Pan, M. \& Sandi, G. 2000. Determination of fractal dimensions of solid carbons from gas and liquid phase adsorption isotherms. Carbon 38(4): 573-588.

Kim, S.K. 2015. Springer Handbook of Marine Biotechnology. Berlin Heidelberg: Springer.

Kotnala, S., Garg, A. \& Chatterj, A. 2009. Screening for the presence of antimicrobial activity in few Indian seaweeds. Pertanika Journal of Tropical Agriculture Science 32: 69-75.

LePape, M.A., Grua-Priol, J. \& Demaimay, M. 2002. Effect of two storage conditions on the odor of an edible seaweed, Palmaria palmata, and optimization of an extraction procedure preserving its odor characteristics. Journal of Food Science 67(8): 3135-3139.

Li, B., Lu, F., Wei, X.J. \& Zhao, R.X. 2008. Fucoidan: Structure and bioactivity. Molecules 13: 1671-1695.

Lim, S.L., Khalafu, S.H.S., Wan Aida, W.M. \& Lim, S.J. 2017. Effects of different precipitation method on physicochemical properties and antioxidant activities of alginates from Sargassum sp. Sains Malaysiana 46(10): 1807-1816.

Lim, S.J., Wan Aida, W.M., Maskat, M.Y., Latip, J., Badri, K.H., Hassan, O. \& Yamin, B.M. 2016. Characterisation of fucoidan extracted from Malaysian Sargassum binderi.Food Chemistry 209: 267-273.

Lim, S.J., Wan Aida, W.M., Maskat, M.Y., Mamot, S., Ropien, J. \& Diah, M.M. 2014. Isolation and antioxidant capacity of fucoidan from selected Malaysian seaweeds. Food Hydrocolloid 42: 280-288.

Manivannan, K., Thirumaran, G., Karthikai, D.G.,Anantharaman, P., Balasubramanian, T.N., Rosfarizan, M., Javad, B., Saeedeh, Z.B., Fahimeh, F. \& Heshu, S.R. 2009. Proximate composition of different group of seaweeds from vedalai coastal waters (Gulf of Mannar): Southeast coast of India. Middle-East Journal of Scientific Research 4: 72-77.

Marsh, H. \& Reinoso, F.R. 2006. Activated Carbon. Netherland: Elsevier.

Miralai, S., Khan, M.M. \& Islam, M.R. 2008. Replacing artificial additives with natural alternatives. Dlm. Nature Science and Sustainable Technology Research Progress, disunting oleh Islam, R. USA: Nova Publishers. hlm. 45-76.

Rashed, M.N. 2013. Adsorption technique for the removal of organic pollutants from water and wastewater. Dlm. Organic Pollutants Monitoring, Risk and Treatment, disunting oleh Rashed, M.N. IntechOpen. hlm. 167-194.
Mohd Fadzelly, A.B., Fifilyana, A.K. \& Perisamy, E. 2015. Comparison of phytochemicals and antioxidant properties of different fruit parts of selected Artocarpus species from Sabah, Malaysia. Sains Malaysiana 44(3): 355-363.

Park, K.Y., Cho, E.H., Kim, N.C. \& Chae, H.J. 2010. Production of fucoidan using marine algae. KSBB Journal 25: 223-229.

Park, P.J., Heo, S.J., Park, E.J., Kim, S.K., Byun, H.G., Jeon, B.T. \& Jeon, Y.J. 2005. Reaction oxygen scavenging effect of enzymatic extracts from Sargassum thunbergii.Journal of Agriculture and Food Chemistry 57: 6666-6672.

Patra, J.K., Rath, S.K., Jena, K., Rathod, V.K. \& Thatoi, H. 2008. Evaluation of antioxidant and antimicrobial activity of seaweed (Sargassum sp.) extract: A study on inhibition of glutathione-s-transferase activity. Turk Journal of Biology 32: 119-125.

Radaideh, J.A., Alazba, A.A., Amin, M.N., Shatnawi, Z.N. \& Amin, M.T. 2016. Improvement of indoor air quality using local fabricated activated carbon from date stones. Sains Malaysiana 45(1): 59-69.

Rajauria, G., Kumar, A., Abu-Ghannam, N. \& Gupta, S. 2010. Effect of hydrothermal processing on colour, antioxidant and free radical scavenging capacities of edible Irish brown seaweeds. International Journal of Food Science and Technology 45: 2485-2493.

Ruperez, P., Ahrazem, O. \& Leal, J.A. 2002. Potential antioxidant capacity of sulphated polysaccharides from edible brown seaweed Fucus vesiculosus. Journal of Agricultural and Food Chemistry 50: 840-845.

Sasidharan, S., Ibrahim, D. \& Mohd Kassim, M.J.N. 2008. Preliminary isolation and in vitro antiyeast activity of active fraction from crude extract of Gracilaria changii. Indian Journal of Pharmacology 40(5): 227-229.

Sharma, R. 2013. Practice and mechanisms of disease. Dlm. Polyphenols in Human Health and Disease, disunting oleh Watson, R.R., Preedy, V.R. \& Zibadi, S. New York: Academic Press. hlm. 757-774.

Shevchenko, N.M., Anastiuk, S.D., Gerasimenko, N.I., Dmitrenok, V.V. \& Zviagintseva, T.N. 2007. Polysaccharide and lipid composition of the brown seaweed Laminaria gurjanovae. Russian Journal of Bioorganic Chemistry 3: 96-107.

Stone, H., Sidle, J., Oliver, S., Woolsey, A. \& Singleton, R.C. 1974. Sensory evaluation by quantitative descriptive analysis. Food Technology 28(11): 24-34.

Synytsya, A., Kim, W.J., Kim, S.M., Pohl, R., Kvasnic, F., Copikova, J. \& Park, Y.I. 2010. Structure and antitumor activity of fucoidan extracted from sporophyll of Korean brown seaweed Undaria pinnatifida. Carbohydrates Polymer 81: 41-48.

Srinivasan, R. \& Sorial, G.A. 2011. Treatment of taste and odor causing compounds 2-methyl isoborneol and geosmin in drinking water. Journal of Environment Sciences 23(1): 1-13.

Yang, C., Chung, D., Shin, I.S., Lee, H.Y., Kim, J.C., Lee, Y.J. \& Sang, G.Y. 2008. Effects of molecular weight and hydrolysis conditions on anticancer activity of fucoidans from sporophyll of Undaria pinnatifida. International Journal of Biological Macromolecules 43(5): 433-437.

Yangthong, M., Towatana, N.H. \& Phromkunthong, W. 2009. Antioxidant activities of four edible seaweeds from the Southern Coast of Thailand. Plant Foods for Human Nutrition 64: 218-223. 
Pusat Bioteknologi dan Makanan Berfungsi

Fakulti Sains dan Teknologi

Universiti Kebangsaan Malaysia

43600 UKM Bangi, Selangor Darul Ehsan

Malaysia
* Pengarang untuk surat-menyurat; email: joe@ukm.edu.my

Diserahkan: 3 Mac 2017

Diterima: 25 Februari 2018 